\title{
Genes frequently associated with sudden death in primary hypertrophic cardiomyopathy
}

\author{
Genes frecuentemente asociados con muerte súbita en miocardiopatía hipertrófica \\ primaria
}

\author{
Diana L. Herrera-Rodríguez ${ }^{1 \neq}$, Armando Totomoch-Serra ${ }^{2,3 \ddagger}$, Sandra Rosas-Madrigal ${ }^{4}$, \\ Claudia Luna-Limón ${ }^{5}$, Daniel Marroquín-Ramírez ${ }^{5}$, Alessandra Carnevale ${ }^{6}$, Rigoberto Rosendo-Gutiérrez ${ }^{6}$, \\ María T. Villarreal-Molina ${ }^{4}$, and Manlio F. Márquez-Murillo5* \\ ${ }^{1}$ Chihuahua Health Services, Secretaría de Salud, Chihuahua; ${ }^{2}$ Department of Genetics and Molecular Biology, Center of Research and Advanced \\ Studies, Instituto Politécnico Nacional (IPN), Mexico City, Mexico; ${ }^{3} \mathrm{PhD}$ Program in Medical Sciences, Universidad de la Frontera, Temuco, Chile; \\ ${ }^{4}$ Laboratory of Cardiovascular Diseases, Instituto Nacional de Medicina Genómica; ${ }^{5}$ Department of Electrocardiology, Instituto Nacional de \\ Cardiología; ${ }^{6}$ Laboratory of Mendelian Diseases, Instituto Nacional de Medicina Genómica, Mexico City, Mexico \\ ¥Authors' contribution was equitable, and the order on the list is arbitrary.
}

\begin{abstract}
Hypertrophic cardiomyopathy (HCM) is characterized by left ventricular hypertrophy without apparent cardiac justification. Sudden cardiac death may be the first manifestation of the disease. It occurs mainly in adulthood and can be seen in childhood and adolescence where genetic origin predominates. Primary HCM ("familial") is inherited in an autosomal dominant pattern in the 25 subtypes informed in Online Mendelian Inheritance in Man. The proteins encoded by the mutated genes are part of the sarcomere in the cardiac cells, being the thick filament the most frequently affected, with the worst prognosis. In the present article, we describe the Mendelian inheritance of the disease and the two most associated genes with sudden death: MYBPC 3 and MYH7.
\end{abstract}

Key words: Hypertrophic cardiomyopathy. Genes. Gene variants. MYBPC3. MYH7. Sudden cardiac death.

\section{Resumen}

La miocardiopatía hipertrófica $(\mathrm{MCH})$ es el aumento de grosor de la pared ventricular izquierda no relacionada con otras alteraciones cardíacas. Es una enfermedad que puede presentar como primera manifestación clínica la muerte súbita y de ahí su relevancia clínica. Aunque se presenta sobre todo en la edad adulta, puede aparecer durante la infancia y adolescencia, en las que predominan los casos de origen hereditario. La MCH primaria, de causa genética, muestra en particular un patrón de herencia autosómico dominante en los 25 subtipos reconocidos en OMIM (Online Mendelian Inheritance in Man). Las proteínas codificadas por los genes mutantes forman parte del sarcómero en células musculares cardíacas, y las variantes patogénicas de filamentos gruesos son las de mayor frecuencia y peor pronóstico. En este artículo se describen la herencia mendeliana de la enfermedad y la relación con muerte súbita de los genes más frecuentemente encontrados en ella: MYBPC3 y MYH7.

Palabras clave: Miocardiopatía hipertrófica. Genes. MYBPC3. MYH7. Variantes genéticas. Muerte súbita.

Correspondence:

*Manlio F. Márquez

E-mail: manlio.marquez@gmail.com
Available online: 09-02-2020 Arch Cardiol Mex (Eng). 2020;90(1):59-68 www.archivoscardiologia.com 2604-7063 / @ 2019 Instituto Nacional de Cardiología Ignacio Chávez. Published by Permanyer. This is an open access article under the CC BY-NC-ND license (http://creativecommons.org/licenses/by-nc-nd/4.0/). 


\section{Introduction}

Hypertrophic cardiomyopathy ( $\mathrm{HCM}$ ) is a heart disease characterized by increased thickness of the left ventricle wall without the presence of blood volume overload or any other heart disease explaining the hypertrophy. ${ }^{1}$

Throughout history, it has been known with different names, including "hereditary ventricular hypertrophy", "hereditary hypertrophic cardiomyopathy", "familial hypertrophic cardiomyopathy", "septal asymmetric hypertrophy" and "idiopathic subaortic stenosis". (In the Spanish language original version of this work, the term "myocardiopathy" was used rather than "cardiomyopathy" for two reasons: a) "myocardiopathy" defines the entity, a disease of the myocardium, and b) the term "cardiomyopathy" is an anglicism, a calque of English cardiomyopathy.)

The European Society of Cardiology classifies HCM in two groups: a) "primary" $\mathrm{HCM}$ or of genetic origin caused by mutations in various genes ${ }^{1}$, and $b$ ) "secondary" HCM consecutive to another disease, such as systemic arterial hypertension, valve disease, or various metabolic syndromes, such as Pompe, Fabry and Danon diseases, which affect the structure of cardiomyocytes. This work focuses on primary HCM.

Primary HCM is considered the most common heart disease of hereditary origin, with a prevalence of 1 in 500 individuals, according to statistical data obtained from the Coronary Artery Risk Development in Young Adults (CARDIA) trial ${ }^{2}$, and it is the sixth most common cause of sudden death in children and young adults in developed countries, according to a study conducted in Australia and New Zealand ${ }^{3}$.

Signs and symptoms appear in the third and fourth decades of life, with a wide variation in the onset and severity of clinical manifestations, from asymptomatic individuals to the presence of syncope, tachyarrhythmias or abrupt onset with sudden death. However, the diagnosis of the disease is established based on morphological changes such as ventricular wall thickening $\geq 13 \mathrm{~mm}$ (measured by echocardiography), with or without obstruction of the outlet tract of the left ventricle ${ }^{4}$, and electrocardiographic changes in repolarization, T-wave inversion in the $\mathrm{DI}$ and $\mathrm{aVL}$ cardiac leads, in addition to QT-intervals prolongation ${ }^{5}$, among other indicators that reflect damage progression and sudden cardiac death risk, with the latter being higher in the 14- to 35-year age group with $\mathrm{HCM}$-secondary symptoms ${ }^{6}$.

\section{Mendelian inheritance in HCM}

Although this is a disease with a well-identified transmission pattern, HCM shows great clinical variability, with age-dependent penetrance, i.e. clinical evolution has great intrafamily and interfamily heterogeneity due to modifying factors that diversify each patient's phenotype. This disease is a good example of "nature versus nurture"

Different genetic and genomic studies have tried to elucidate the causes of this hereditary anomaly and have identified DNA modifications, known as genetic variants and classified as benign, likely benign, of uncertain significance, likely pathogenic and pathogenic, which may cause structural changes in sarcomeric proteins of the heart muscle, which favors ventricular hypertrophy, predominantly of the left ventricle.

In general, primary HCM has a Mendelian inheritance pattern of the autosomal dominant type, i.e., the children of an affected subjects possess a $50 \%$ risk for inheriting the mutated allele and therefore will suffer from the disease. However, there are de novo cases who have no family history and, even so, affected individuals show an identified pathogenic variant they will inherit to their offspring with the same probability $(50 \%)^{8}$; on the other hand, there are reports of cases that show mutations in the MYL3, MYH7 and MYBPC3 genes that suggest a pattern of autosomal recessive inheritance, which should be considered at the time of taking patient history. For this reason, some investigations have tried to elucidate the functional effect of genetic variants that give rise to cardiac alterations, with the purpose to facilitate diagnosis and offer early treatment, even in asymptomatic patients. For the moment, identification of the causal variants, and their functional effect, helps to understand the mechanism that generates hypertrophy and to predict damage severity.

Thanks to the use of next-generation sequencing (NGS), the number of genes related to HCM has significantly increased in the past few years ${ }^{9-11}$, with more than 50 published genes and nearly 8,000 variants (Table 1) in the PubMed/MEDLINE database related to this disease, out of which only 25 are consistent with the gene compendium Online Mendelian Inheritance in Man (OMIM; http: www.omim.org), where clinical characteristics, genes with the most common pathogenic identified variants and the pathophysiological consequences of these molecular changes are described.

\section{Cardiac cells structure and proteins underlying $\mathrm{HCM}$}

Cardiomyocytes are made up of five components: a) tubules and sarcolemma, b) sarcoplasmic reticulum, c) 
Table 1. Genes and type of variants related to primary cardiomyopathy

\begin{tabular}{|c|c|c|c|c|c|c|}
\hline \multirow[t]{2}{*}{ Gene } & \multirow[t]{2}{*}{ HCM type } & \multirow[t]{2}{*}{ Frequency } & \multirow[t]{2}{*}{ No info } & \multicolumn{3}{|c|}{ Type of described variant (OMIM)* } \\
\hline & & & & BEN & РATH & UNC \\
\hline ACTC $1^{12-17}$ & $11^{\mathrm{a}}$ & Rare $<1 \%$ & 29 & 8 & 29 & 30 \\
\hline TNNC $1^{18}$ & $13^{\mathrm{a}}$ & Rare $<1 \%$ & 17 & 4 & 7 & 8 \\
\hline TNN/3 $13,14,19-24$ & $7^{\mathrm{a}}$ & Rara $<5 \%$ & 47 & 7 & 73 & 39 \\
\hline TNNT2 $2^{13,14,19,21,22,25-27}$ & $2^{\mathrm{a}}$ & Rare $<5 \%$ & 65 & 11 & 81 & 53 \\
\hline TPM113,14,26,28,29 & $3^{a}$ & Rare $<5 \%$ & 83 & 10 & 29 & 51 \\
\hline MYBPC $3^{13,14,17,21,22,26,30,31-55}$ & $4^{b}$ & $15-25 \%$ & 241 & 42 & 1014 & 302 \\
\hline$M Y H 6^{23,26,56}$ & $14^{\mathrm{b}}$ & Rare $<1 \%$ & 183 & 7 & 3 & 13 \\
\hline$M Y H 7^{13,14,17,21-23,30-32,49-52,55,57-69}$ & $1^{\mathrm{b}}$ & $15-25 \%$ & 300 & 41 & 872 & 317 \\
\hline MYL2 $2^{13,17,29,70-72}$ & $10^{\mathrm{b}}$ & Rare $<2 \%$ & 37 & 18 & 25 & 24 \\
\hline$M Y L 3^{13,14,69,73-75}$ & $8^{b}$ & Rare $<1 \%$ & 21 & 5 & 30 & 21 \\
\hline ACTN2 $2^{13-15,76,77}$ & $23^{c}$ & Rare $<1 \%$ & 76 & 30 & 9 & 45 \\
\hline $\operatorname{CSRP3}^{78,79}$ & $12^{c}$ & Rare $<1 \%$ & 24 & 9 & 5 & 12 \\
\hline$\angle D B 3^{80}$ & $24^{c}$ & Rare $1-5 \%$ & 151 & 8 & 0 & 5 \\
\hline MYOZ267,81 & $16^{c}$ & Rare $<1 \%$ & 36 & 1 & 8 & 2 \\
\hline$M Y P N^{\beta 2}$ & $22^{c}$ & Rare $<5 \%$ & 42 & 39 & 4 & 30 \\
\hline$N E X N^{\beta 3}$ & $20^{c}$ & Rare $<1 \%$ & 35 & 10 & 4 & 45 \\
\hline TCAP 84 & $25^{c}$ & Rare $<1 \%$ & 31 & 1 & 0 & 4 \\
\hline $\operatorname{TTN}^{15,26,51,72,85}$ & $g^{c}$ & Rare $<5 \%$ & 3949 & 2 & 12 & 20 \\
\hline$V C L^{86}$ & $15^{c}$ & Rare $<1 \%$ & 54 & 24 & 3 & 30 \\
\hline$C A L R^{387}$ & $19^{d}$ & Rare $<5 \%$ & 4 & 0 & 0 & 1 \\
\hline$J P H 2^{88,89}$ & $17^{d}$ & Rare $<1 \%$ & 6 & 13 & 6 & 15 \\
\hline$P L N^{90}$ & $18^{d}$ & Rare $<1 \%$ & 7 & 0 & 5 & 5 \\
\hline CAV3 $3^{91}$ & $1^{e}$ & Rare $<5 \%$ & 54 & 11 & 5 & 8 \\
\hline$M Y L K 2^{92}$ & $1^{e}$ & Rare $<5 \%$ & 39 & 17 & 3 & 7 \\
\hline PRKAG2 $2^{93-98}$ & $6^{\mathrm{e}}$ & Rare $1 \%$ & 100 & 1 & 31 & 4 \\
\hline
\end{tabular}

*Information obtained from PubMed up to April 2018.

OMIM: Online Mendelian Inheritance in Man; No info: no information in medical publications; BEN: benign; PATH: pathogenic; UNC: uncertain; a: thin filament protein; b: thick filament protein; c: Z-disk protein; d: proteins included in the management of Ca+; e: other related proteins.

contractile elements, d) mitochondria and e) nucleus. The contractile unit is known as sarcomere, which is formed by thick and thin filaments whose most important proteins are myosin and actin (Fig. 1). Thick filaments are formed by heavy chains of the $\beta$-myosin protein. This is a hexameric protein composed of two essential light chains encoded by the MYL2 gene, two regulatory light chains encoded by the MYL3 gene, and two heavy chains encoded by the MYH7 gene, as well as myosin-binding protein C (MYBPC3 gene). The thin filaments are made upof actin
(ACTC1 and ACTA1 genes), the troponin complex (TNNC1, TNNI3, TNNT2 genes) and tropomyosin (encoded by the TPM1 gene) (Fig. 1). The alteration of one or several cardiomyocyte components has direct or indirect repercussions on the development of primary $\mathrm{HCM}^{7,8}$.

\section{Alterations in thick and thin myofilaments}

Some studies have shown that the pathogenic variants in genes that encode thick and thin filament 


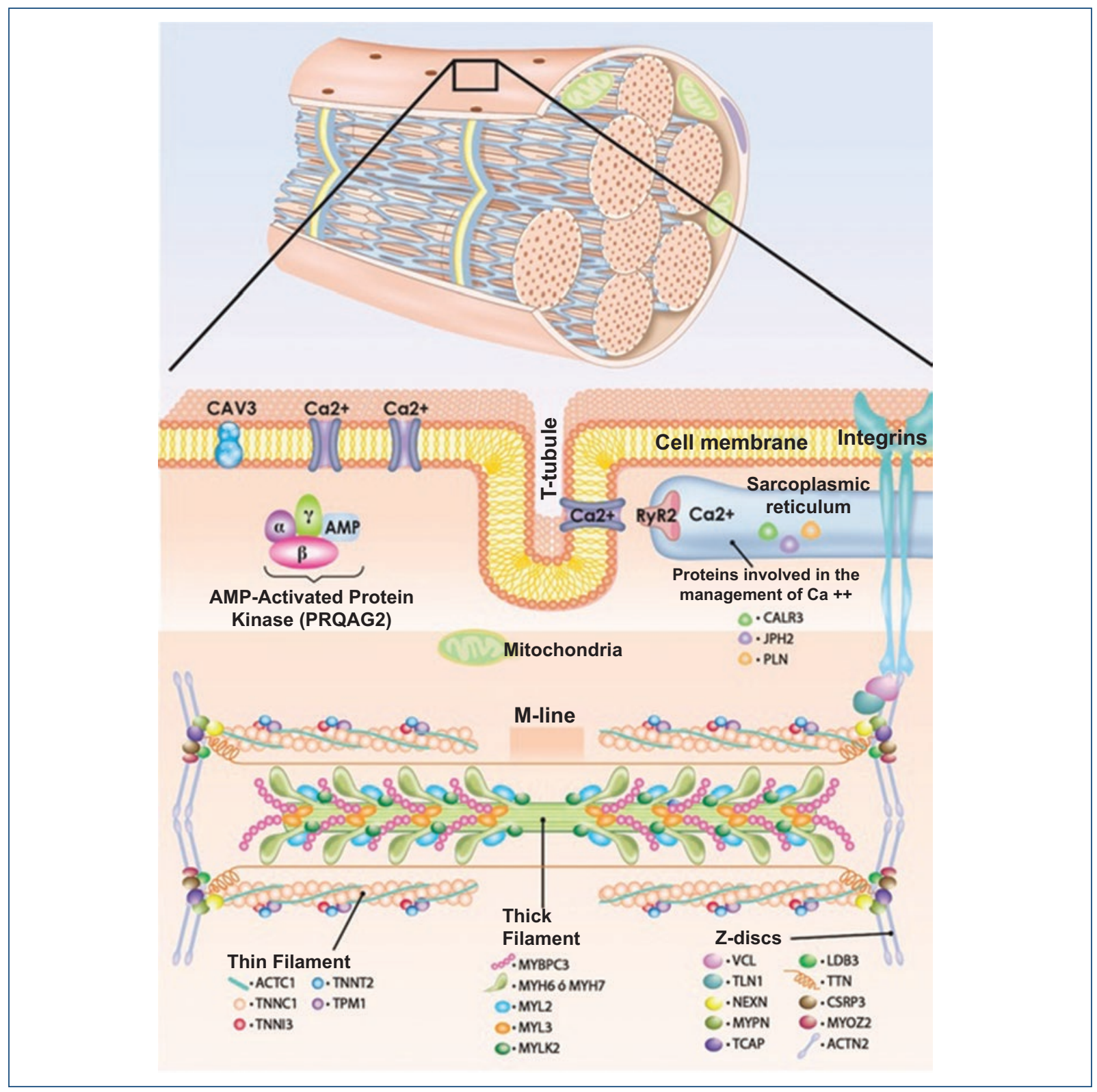

Figure 1. Cardiac skeletal muscle sarcomere. Proteins localized in the cardiac muscle sarcomere and whose pathogenic variants are related to primary hypertrophic cardiomyopathy are shown.

proteins lead to an energy expenditure increase due to an alteration in ATP use and metabolism" 10 . This "energy compromise" might result in a neuroendocrine system activation in order to develop compensatory cardiac hypertrophy. To study the functional effects of pathogenic variants, Coppini et al. ${ }^{11}$ conducted a $4.5-$ year prospective study, where they divided a group of affected individuals according to the altered structure, and thus two groups were formed: one where the patients $(n=80)$ were carriers of thin filament pathogenic variants and other $(n=150)$ with pathogenic thick filament variants, and found that patients with thin filament alterations showed higher left ventricular dysfunction and heart failure, in comparison with the group of thick filament alterations, which had more fibrosis, less hypertrophy with atypical distribution, severe diastolic dysfunction, abnormal blood pressure response during exercise and a family history of sudden cardiac death. On the other hand, individuals with pathogenic variants that affect thick filaments suffered higher obstruction of the left ventricular outflow tract due to a pronounced growth of the ventricular wall ${ }^{11}$. In another 
Table 2. Sarcomere genes whose pathogenic or probably pathogenic variants are related to HCM and sudden death

\begin{tabular}{|c|c|c|c|c|c|}
\hline Gene & Locus & MIM & Protein & Inheritance & FHSD \\
\hline \multicolumn{6}{|c|}{ Genes that encode thin filament proteins } \\
\hline TNNC1 & $3 p 21.1$ & 613243 & Type 1 troponin C & $A D$ & Yes $^{18}$ \\
\hline TNNI3 & $19 q 13.42$ & 613690 & Type 3 troponin I & $A D$ & Yes $^{19,20}$ \\
\hline TNNT2 & $1 \mathrm{q} 32.1$ & 115195 & Type 2 troponin $\mathrm{T}$ & $A D$ & Yes $^{25}$ \\
\hline TPM1 & $15 q 22.2$ & 115196 & Tropomyosin 1 & $A D$ & $Y_{e s}^{28,99}$ \\
\hline ACTC1 & $15 q 14$ & 612098 & Actin alpha cardiac muscle 1 & $A D$ & Yes $^{12}$ \\
\hline \multicolumn{6}{|c|}{ Genes that encode thick filament proteins } \\
\hline МYBPC3 & $11 \mathrm{p} 11.2$ & 115197 & Cardiac myosin-binding protein $\mathrm{C}$ & $A D / A R$ & Yes $^{23,43,47,49,55,74,100-103}$ \\
\hline MYH6 & $14 q 11.2$ & 613251 & Alpha-myosin heavy chain & $A D$ & $Y_{e} s^{56}$ \\
\hline MYH7 & $14 q 11.2$ & & Beta-myosin heavy chain & $A D / A R$ & Yes $46,49,55,57,58,67,100,104,105$ \\
\hline MYL2 & $12 q 24.11$ & 608758 & $\begin{array}{l}\text { Ventricular regulatory myosin light } \\
\text { chain }\end{array}$ & $A D$ & Yes $^{70,71}$ \\
\hline MYL3 & $3 \mathrm{p} 21.31$ & 608751 & Myosin 3 light chain & $A D / A R$ & Yes $^{36,73-75,106}$ \\
\hline
\end{tabular}

MIM: corresponding number in the Mendelian Inheritance in Man database; FHSD: family history of sudden death; AD: autosomal dominant; AR: autosomal recessive.

study, where nine genes were analyzed in $197 \mathrm{HCM}$ index-cases (including 172 familial cases and 25 apparently sporadic cases), Richard et al. ${ }^{107}$ found pathogenic variants in $63 \%$ of cases; out of these, $42 \%$ were found in the MYBPC3 gene sequence and $40 \%$ in $\mathrm{MYH} 7^{7}$. Both genes encode thick filament proteins, and it should be noted that this type of findings are repeated across various investigations ${ }^{108,109}$ in different ethnic groups. The above turns the MYBPC3 and MYH7 genes into the main subject of study in cases of $\mathrm{HCM}$ with a family history of sudden death or non-lethal cardiac arrest (Table 2).

\section{The MYBPC3 gene and its role in $\mathrm{HCM}$}

The MYBPC3 gene is located in chromosome 11 short arm, which encodes the cardiac myosin-binding protein $C$ isoform (MYBPC or MyBPC). This protein is expressed only in the cardiac muscle and is localized specifically in the sarcomere transverse A bands, bound to myosin heavy chains in thick filaments; therefore, it is considered a member of the tripartite complex together with actin and myosin, and thus it regulates cardiac contraction through phosphorylation events ${ }^{101,110}$.

The mechanism by means of which its pathogenic variants lead to the development of $\mathrm{HCM}$ is still a matter of discussion, but two hypotheses have been proposed. One of them attributes clinical manifestations of haploinsufficiency, with an increased sensitivity to calcium $^{111}$, while the second favors the hypothesis of a toxic effect of the altered protein ${ }^{112}$.

The study of the MYBPC3 gene gained interest due to the increasingly common use of molecular biology technologies for diagnosis, which have found a consistent relationship between pathogenic variants of this gene and the development of $\mathrm{HCM}^{113}$, and thus far, more than 450 pathogenic or probably pathogenic variants have been documented in the Human Gene Mutation Database (HGMD; http://www.hgmd.cf.ac.uk).

The molecular study in cases of sudden death led various researchers to the association with $\mathrm{HCM}$ due to the presence of pathogenic variants in proteins that are involved in the functioning of the sarcomere. In this context, Cann et al. ${ }^{49}$ carried out a study of molecular necropsy in 96 cases of sudden cardiac death and identified 50 cases with cardiomyopathy, out of which 15 had HCM, and out of these, three exhibited pathogenic variants in the MYBPC3 gene and had a history of sudden death of cardiac origin during exercise, immediately after exercise or during sleep ${ }^{49}$. Late-onset clinical characteristics and a high frequency of a family history of sudden death in those affected do repeat across multiple studies in different populations around the world 53,113 . 


\section{The $M Y H 7$ gene and its role in $\mathrm{HCM}$}

The MYH7 gene is localized at chromosome 14 long arm and encodes the myosin heavy chain $\beta$ isoform (MYH or $\beta-\mathrm{MHC}$ ), a protein that is expressed in the striated muscle of mammals (predominantly in the ventricles) and that is part of the sarcomere thick filaments ${ }^{114}$. MYH7 is the first gene whose pathogenic variants were associated with $\mathrm{HCM}$ and whose negative dominant effect is well described ${ }^{115,116}$.

So far, more than 350 pathogenic variants have been documented in the MYH7 gene in HGMD, with highly variable clinical phenotypes, as in the cohort study by García-Castro et al. ${ }^{108}$ in 120 unrelated patients with $\mathrm{HCM}$. The subjects of this study were underwent history taking and molecular study, with 31 different pathogenic variants being identified in 32 patients, $8 \%$ of whom (10 patients) had alterations in the MYH7 gene; mean age at which the diagnosis was established was 35 years, and 3 out of these 10 patients $(70 \%)$ had a family history of $\mathrm{HCM}^{108}$.

As for the prognosis for MYH7 gene pathogenic variants carriers, Wang et al. ${ }^{117}$ reported in 2008 that the pathogenic variants of this gene produce more aggressive phenotypes in comparison with those that affect the MYBPC3 gene, with early-onset manifestations (16 years of age) and high risk of sudden death $^{117}$.

Various investigations have tried to establish the genotype-phenotype correlation in order to facilitate early diagnosis in asymptomatic subjects, but this has been difficult to establish due to the large number of pathogenic variants identified in different genes (locus heterogeneity), to a possible additive effect that modifies the phenotype as in the case of age at presentation and prognosis, to a high clinical variability of this disease and influence of the environment ${ }^{48}$.

\section{Pathogenic or probably pathogenic variants located in MYBPC3 and MYH7 in relation to sudden death}

Currently, there are a dozen pathogenic or probably pathogenic variants related to sudden death in different populations around the world; most of them produce a reading frameshift and, as a consequence, the synthesized protein is truncated due to a premature termination codon. Below, some of them are synthetically described within the context of sudden death.

\section{Variants related to $\mathrm{HCM}$ and history of sudden death for the MYBPC3 gene}

p.Glu542GIn: This change has been described in seven unrelated index cases. In the molecular plane, the last nucleotide of a consensus splice site is disrupted, and as an effect, a short protein of 486 amino acids is obtained ${ }^{118}$.

p.Cys719Arg: This change was identified in 2017 in an apparently sporadic case of Chinese ancestry whose cause of death was unknown and, in the death report, sudden death was concluded ${ }^{47}$.

p.Glu334Lys: It was identified in a 48-year-old man of Korean ancestry, diagnosed by echocardiography as a phenocopy of the Brugada syndrome at admission diagnosis. He was survivor of a non-lethal cardiac arrest ${ }^{100}$.

p.Pro108Alafs ${ }^{*}$ : This is an insertion of the GCTGGCCCCTGCC nucleotides at exon 3 position 29. The variant was initially identified in 13 families from southern Spain; therefore, 107 relatives were studied and, out of them, 39 had HCM, with male predominance and with five documented cases of sudden death and enlarged left ventricular mass in carriers of this variant ${ }^{43}$. In the protein, length is reduced to 115 amino acids, out of which eight are new.

p.Gly1093Cys: 96 necropsies of sudden death cases were analyzed, among which one proband had died immediately after practicing exercise, which is why genetic testing of 12 relatives was requested, eight of which were positive for this change and two cases had cardiac symptoms related to $\mathrm{HCM}^{49}$.

p.Arg668His: The index case apparently died during sleep, which is why 27 relatives were studied, out of which 10 were positive for the variant and four experienced symptoms related to $\mathrm{HCM}^{49}$. This variant had already been previously reported ${ }^{119}$.

p.Arg502Trp: The index case died while practicing exercise, which is why five relatives underwent genetic testing, out of which three were positive, one of them with symptoms related to $\mathrm{HCM}^{49}$.

IVS5+5G $\rightarrow$ C: This variant corresponds to a substitution of cytokine by guanine five base pairs downstream of the 5' splice donor site in intron 5 of the MYBPC3 gene. This modification causes a change in the reading frame and incorporates 15 amino acids after position 165 , which ultimately causes a truncated protein. Lin et al. report the case of a family with a history of sudden death in the proband's brother, who died at 20 years of age. Both the father and the proband are HCM clinical carriers ${ }^{120}$. 
p.F305Pfs*27: This is a deletion of two thymines in exon 11 that causes a termination codon and therefore a truncated protein. Calore et al. studied a series of 97 probands of Italian origin diagnosed with $\mathrm{HCM}$, out of which 19 were carriers of the variant, plus 45 carriers detected by cascade screening. Penetrance in this series of patients was $75 \%$; in eight carriers there was a family history of sudden death, and the prognosis is therefore reserved for those with the variant after the fourth decade of life ${ }^{52}$.

Lys1209Serfs*28: In combination with p.Gly100Ser, found in PRKAG2 (probable additive effect), Zhao et al. studied 18 patients diagnosed with $\mathrm{HCM}$, among which one proband had two variants and a history of sudden death in the mother and maternal grandmother; the proband phenotype is consistent with severe hypertrophy and $\mathrm{HCM}$ early onset ${ }^{23}$.

\section{Variants related to $\mathrm{MCH}$ and history of sudden death for the MYH7 gene}

p.Arg453Cys: In this variant, a change of charge is observed due to an amino acid change, and thus, a more aggressive phenotype has been reported in comparison with Val606Met and Phe85Cys ${ }^{121,122}$. Ko et al. studied a group of 20 individuals originating in one family, all of them older than 16 years; in 11 cases, clinical HCM was suspected, and in seven, the disease was confirmed by echocardiography. This family has a history of three cases of sudden death and two with end-stage heart disease ${ }^{108}$.

p.Arg1045Leu: In this family, whose proband passed away during sleep, four individuals were studied, out of whom one relative was identified with clinical data consistent with $\mathrm{HCM}^{49}$.

p.Arg719Trp: Anan et al. conducted a genetic study in four different families with a history of HCM and at least 22 cases of sudden death, which determined a higher risk of adverse effects for the carriers of the variant ${ }^{123}$.

p.Asn391Thr: Feng et al. studied an extended family of the Han ethnic group (China) diagnosed with HCM, which included three generations and 22 individuals, out of which three died with a diagnosis of $\mathrm{HCM}$; the age at disease symptoms onset was in most cases $<20$ years ${ }^{58}$.

p.Gly716Arg: Hwang et al. studied a Korean family composed of 32 members belonging to four generations. In this family, there was a history of four individuals with sudden death at an early age; genetic testing showed that 13 individuals were carriers of the variant ${ }^{124}$.

p.Arg403GIn: Marian et al. studied a family with seven positive cases for this variant. In this family, the onset of symptoms occurred on average at 22 years of age; however, a 10-year-old male individual was asymptomatic. Kaplan-Meier survival analysis showed that p.Arg403GIn variant carriers have an $11 \%$ likelihood of remaining alive at 60 years of age ${ }^{125}$. This variant had been previously reported with a high incidence of sudden death in other three families ${ }^{126-128}$.

p.Arg453Cys: This variant was recognized in the 1990 decade in a family with 13 individuals affected with $\mathrm{HCM}$ and a history of six sudden death cases. Initially, screening for the detection of variants was carried out with the help of ribonuclease protection studies, and at the familiar level, the disease was associated with the variant found by means of linkage analysis; this change produces a modification in amino acid charge (-1) and has been related to lower survival ${ }^{128}$.

p.Glu848Gly: This glutamic acid substitution by glycine gives raise to a negative dominant effect by altering the protein-protein (MYH7-MYPC3) bonds that drive to systolic dysfunction and increased risk of sudden death ${ }^{67}$.

p.Asn391Thr: Nonsense variant found during the study of a family originating in China that had multiple individuals affected by HCM and a history of four members with sudden death ${ }^{58}$.

\section{Conclusion}

$\mathrm{MCH}$ is a highly heterogeneous disease due to the large number of affected genes and genes identified as causal factors; in addition, the presence of one or more mutations in proteins that make up the contractile apparatus of the cardiac muscle and, ultimately, environmental influence, give rise to a particular phenotype with variable clinical course, in which sudden death can be the first manifestation. Among the genes that encode proteins that are part of the cardiac muscle contractile apparatus, thick filament MYBPC3 and MYH7 genes are the most frequently identified as causal factors in world medical publications, considering all populations, with more than 350 pathogenic or probably pathogenic variants reported for each gene.

\section{Conflict of interests}

None.

\section{Funding}

The present investigation has not received any specific grant from public or commercial sector agencies or nonprofit entities. 


\section{Ethical disclosures}

Protection of people and animal subjects. The authors declare that no experiments were performed on humans or animals for this study.

Confidentiality of data. The authors declare that no patient data appear in this article.

Right to privacy and informed consent. The authors declare that no patient data appear in this article.

\section{Acknowledgements}

The authors appreciate Leonardo Olguín Landa's collaboration in the creation of figure 1.

\section{References}

1. Elliott $P$, Andersson B, Arbustini E, Bilinska Z, Cecchi F, Charron P, et al Classification of the cardiomyopathies: a position statement from the European Society Of Cardiology Working Group on Myocardial and Pericardial Diseases. Eur Heart J 2008(2);29:270-6.

2. Maron BJ, Gardin JM, Flack JM, Gidding SS, Kurosaki TT, Bild DE. Prevalence of hypertrophic cardiomyopathy in a general population of young adults. Echocardiographic analysis of 4111 subjects in the CARDIA Study. Coronary Artery Risk Development in (Young) Adults. Circulation 1995(4):92:785-9.

3. Bagnall RD, Weintraub RG, Ingles J, Duflou J, Yeates L, Lam L, et al. A prospective study of sudden cardiac death among children and young adults. N Engl J Med 2016(25);374:2441-52.

4. Michels M, Soliman OI, Phefferkorn J, Hoedemaekers YM, Kofflard MJ, Dooijes D, et al. Disease penetrance and risk stratification for sudden cardiac death in asymptomatic hypertrophic cardiomyopathy mutation carriers. Eur Heart J 2009(21);30:2593-8.

5. McKenna WJ, Spirito P, Desnos M, Dubourg O, Komajda M. Experience from clinical genetics in hypertrophic cardiomyopathy: proposal for new diagnostic criteria in adult members of affected families. Heart 1997(2);77:130-2

6. Brugada J. Sudden death in hypertrophic myocardiopathy. Rev Esp Cardiol 1998(12);51:991-6.

7. Sirker A, Shah AM. Biochemistry and physiology of cardiac muscle. Medicine 2010(7);38:340-3.

8. Tian T, Liu Y, Zhou X, Song L. Progress in the molecular genetics of hypertrophic cardiomyopathy: a mini-review. Gerontology 2013(3);59:199-205.

9. Crilley JG, Boehm EA, Blair E, Rajagopalan B, Blamire AM, Styles P, et al. Hypertrophic cardiomyopathy due to sarcomeric gene mutations is characterized by impaired energy metabolism irrespective of the degree of hypertrophy. J Am Coll Cardiol 2003(10);41:1776-82.

10. Ashrafian H, Redwood C, Blair E, Watkins H. Hypertrophic cardiomyopathy: a paradigm for myocardial energy depletion. Trends Genet 2003(5);19:263-8.

11. Coppini R, Ho CY, Ashley E, Day S, Ferrantini C, Girolami F, et al. Clinical phenotype and outcome of hypertrophic cardiomyopathy associated with thin-filament gene mutations. J Am Coll Cardiol 2014(24);64:2589-600.

12. Monserrat L, Hermida-Prieto M, Fernández X, Rodríguez I, Dumont C Cazón $\mathrm{L}$, et al. Mutation in the alpha-cardiac actin gene associated with apical hypertrophic cardiomyopathy, left ventricular non-compaction, and septal defects. Eur Heart J 2007(16);28:1953-61.

13. Gómez J, Lorca R, Reguero JR, Morís C, Martín M, Tranche S, et al Screening of the filamin $c$ gene in a large cohort of hypertrophic cardiomyopathy patients. Circ Cardiovasc Genet 2017(2);10:e001584.

14. Ingles J, Burns C, Bagnall RD, Lam L, Yeates L, Sarina T, et al. Nonfamilial hypertrophic cardiomyopathy: prevalence, natural history, and clinical implications. Circ Cardiovasc Genet 2017(2);10:e001620.

15. Frustaci A, De Luca A, Guida V, Biagini T, Mazza T, Gaudio C, et al. Novel $\alpha$-actin gene mutation $p$.(ala21val) causing familial hypertrophic cardiomyopathy, myocardial noncompaction, and transmural crypts. Clinical-pathologic correlation. J Am Heart Assoc 2018(4);7:e008068.

16. Yang QL, Bian YY, Wang B, Zuo L, Zhou MY, Shao H, et al. Novel phenotype-genotype correlations of hypertrophic cardiomyopathy caused by mutation in $\alpha$-actin and myosin-binding protein genes in three unrelated Chinese families. J Cardiol 2018(18); S0914-5087:30328-9.

17. Nagyova E, Radvanszky J, Hyblova M, Simovicova V, Goncalvesova E, Asselbergs FW, et al. Targeted next-generation sequencing in Slovak cardiomyopathy patients. Bratisl Lek Listy 2019(1;120):46-51.
18. Chung WK, Kitner C, Maron BJ. Novel frameshift mutation in troponin C (TNNC1) associated with hypertrophic cardiomyopathy and sudden death. Cardiol Young 2011(3);21:345-8.

19. Van Driest SL, Ellsworth EG, Ommen SR, Tajik AJ, Gersh BJ, Ackerman MJ. Prevalence and spectrum of thin filament mutations in an outpatient referral population with hypertrophic cardiomyopathy. Circulation 2003(4): 108:445-51.

20. Rani DS, Nallari P, Priyamvada S, Narasimhan C, Singh L, Thangaraj K. High prevalence of arginine to glutamine substitution at 98, 141 and 162 positions in troponin I (TNNI3) associated with hypertrophic cardiomyopathy among Indians. BMC Med Genet 2012;13:69.

21. Zigova M, Bernasovska J, Boronova I, Mydlarova Blascakova M, Kmec J. Finding the candidate sequence variants for diagnosis of hypertrophic cardiomyopathy in East Slovak patients. J Clin Lab Anal 2018(3);32:e22303.

22. Mademont-Soler I, Mates J, Yotti R, Espinosa MA, Pérez-Serra A, Fernandez-Avila Al, et al. Additional value of screening for minor genes and copy number variants in hypertrophic cardiomyopathy. PLoS One 2017(8):12:e0181465

23. Zhao Y, Feng $Y$, Ding $X$, Dong S, Zhang H, Ding J, et al. Identification of a novel hypertrophic cardiomyopathy-associated mutation using targeted next-generation sequencing. Int J Mol Med 2017(1);40:121-9.

24. Sohn DW, Kim HK, Kim YJ, Oh S, Seong MW, Park SS. Cardiomyopathies with mixed and inapparent morphological features in cardiac troponin i3 mutation. Korean Circ J 2017(3);47:413-7.

25. Anan $\mathrm{R}$, Shono $\mathrm{H}$, Kisanuki A, Arima S, Nakao S, Tanaka H. Patients with familial hypertrophic cardiomyopathy caused by a Phe110lle missense mutation in the cardiac troponin $T$ gene have variable cardiac morphologies and a favorable prognosis. Circulation 1998(5);98:391-7.

26. Mendes de Almeida R, Tavares J, Martins S, Carvalho T, Enguita FJ, Brito $D$, et al. Whole gene sequencing identifies deep-intronic variants with potential functional impact in patients with hypertrophic cardiomyopathy. PLoS One 2017(8);12:e0182946.

27. Biswas A, Das S, Kapoor M, Shamsudheen KV, Jayarajan R, Verma A, et al. Familial hypertrophic cardiomyopathy - identification of cause and risk stratification through exome sequencing. Gene 2018:660:151-156.

28. Karibe A, Tobacman LS, Strand J, Butters C, Back N, Bachinski LL, et al. Hypertrophic cardiomyopathy caused by a novel alpha-tropomyosin mutation (V95A) is associated with mild cardiac phenotype, abnormal calcium binding to troponin, abnormal myosin cycling, and poor prognosis. Circulation 2001(1);103:65-71.

29. Renaudin P, Janin A, Millat G, Chevalier P. A novel missense mutation p.gly162glu of the gene myl2 involved in hypertrophic cardiomyopathy: a pedigree analysis of a proband. Mol Diagn Ther 2018(2);22:219-223.

30. Weissler-Snir A, Hindieh W, Gruner C, Fourey D, Appelbaum E, Rowin E, et al. Lack of phenotypic differences by cardiovascular magnetic resonance imaging in myh7 ( $\beta$-myosin heavy chain)- versus mybpc3 (myosin-binding protein c)-related hypertrophic cardiomyopathy. Circ Cardiovasc Imaging 2017(2);10:e005311.

31. McTaggart DR, Ogden KJ, Marathe JA. A long term follow-up study of carriers of hypertrophic cardiomyopathy mutations. Heart Lung Circ 2017(1);26:18-24.

32. Chida A, Inai K, Sato H, Shimada E, Nishizawa T, Shimada M. Prognostic predictive value of gene mutations in Japanese patients with hypertrophic cardiomyopathy. Heart Vessels 2017(6);32:700-7.

33. Cirino AL, Lakdawala NK, McDonough B, Conner L, Adler D, Weinfeld $\mathrm{M}$, et al. A comparison of whole genome sequencing to multigene panel testing in hypertrophic cardiomyopathy patients. Circ Cardiovasc Genet 2017(5);10:e001768.

34. Kissopoulou A, Trinks C, Green A, Karlsson J, Jonasson J, Gunnarsson C. Homozygous missense MYBPC3 Pro873His mutation associated with increased risk for heart failure development in hypertrophic cardiomyopathy. ESC Heart Fail 2018(4);5:716-23.

35. Lorca R, Gómez J, Martín M, Cabanillas R, Calvo J, León V, et al. Insights into hypertrophic cardiomyopathy evaluation through follow-up of a founder pathogenic variant. Rev Esp Cardiol (Engl Ed) 2019(2); 72:138-44.

36. Nomura A, Tada $\mathrm{H}$, Teramoto $\mathrm{R}$, Konno $\mathrm{T}$, Hodatsu $\mathrm{A}$, Won $\mathrm{HH}$, et al. Whole exome sequencing combined with integrated variant annotation prediction identifies a causative myosin essential light chain variant in hypertrophic cardiomyopathy. J Cardiol 2016(2);67:133-9.

37. Zhou N, Qin S, Liu Y, Tang L, Zhao W, Pan C, et al. Whole-exome sequencing identifies rare compound heterozygous mutations in the MYBPC3 gene associated with severe familial hypertrophic cardiomyopathy. Eur J Med Genet 2018(17)S1769-7212:30728-0.

38. Hallıoğlu Kılınç O, Giray D1, Bişgin A, Tuğ Bozdoğan S, Karpuz D. Familial hypertrophic cardiomyopathy: a case with a new mutation in the MYBPC3 gene. Turk Kardiyol Dern Ars 2017(5);45:450-3.

39. McNamara JW, Li A, Lal S, Bos J, Harris S, van der Velden J. MYBPC3 mutations are associated with a reduced super-relaxed state in patients with hypertrophic cardiomyopathy. PLoS One 2017(6);12:e0180064.

40. Szabadosova V, Boronova I, Ferenc P, Tothova I, Bernasovska J, Zigova $\mathrm{M}$, et al. Analysis of selected genes associated with cardiomyopathy by next-generation sequencing. J Clin Lab Anal 2018(2;32). 


\section{D.L. Herrera-Rodríguez, et al.: Genes and sudden death in HCM}

41. Rafael JF, Cruz FEDS Filho, Carvalho ACC, Gottlieb I, Cazelli JG, Siciliano AP, et al. Myosin-binding protein c compound heterozygous variant effect on the phenotypic expression of hypertrophic cardiomyopathy. Arq Bras Cardiol 2017(4);108:354-60.

42. Zhao B, Wang S, Chen J, Ji Y, Wang J, Tian X, et al. Echocardiographic characterization of hypertrophic cardiomyopathy in Chinese patients with myosin-binding protein C3 mutations. Exp Ther Med 2017(3)13;995-1002.

43. Sabater-Molina M, Saura D, García-Molina Sáez E, González-Carrillo J, Polo L, Pérez-Sánchez I, et al. A novel founder mutation in mybpc3: phenotypic comparison with the most prevalent mybpc3 mutation in Spain. Rev Esp Cardiol (Engl Ed) 2017(2);70:105-14.

44. Cen X, Zheng J, Hu X, Qu B. Severe apical hypertrophic cardiomyopathy with Ser 236 Gly mutation in MYBPC3: A three-year follow-up investigation. Hellenic J Cardiol 2017(5);58:366-8.

45. Bottillo I, D'Angelantonio D, Caputo V, Paiardini A, Lipari M, De Bernardo $C$, et al. Molecular analysis of sarcomeric and non-sarcomeric genes in patients with hypertrophic cardiomyopathy. Gene 2016(2);577:227-35

46. Mathew J, Zahavich L, Lafreniere-Roula M, Wilson J, George K Benson L, et al. Utility of genetics for risk stratification in pediatric hypertrophic cardiomyopathy. Clin Genet 2018(2);93:310-9.

47. Xu CC, Bai YZ, Xu XS, Lü GL, Lai XP, Chen R. Gene analysis for the sudden death of hypertrophic cardiomyopathy by whole exome sequencing. Fa Yi Xue Za Zhi 2017(4);33:339-43.

48. Zhang X, Xie J, Zhu S, Chen Y, Wang L, Xu B. Next-generation sequencing identifies pathogenic and modifier mutations in a consanguineous Chinese family with hypertrophic cardiomyopathy. Medicine (Baltimore) 2017(24);96:e7010.

49. Cann F, Corbett M, O'Sullivan D, Tennant S, Hailey H, Grieve JH, et al Phenotype-driven molecular autopsy for sudden cardiac death. Clin Genet 2017(1);91:22-9.

50. Mak CM, Chen SP, Mok NS, Siu WK, Lee HH, Ching CK, et al. Genetic basis of channelopathies and cardiomyopathies in Hong Kong Chinese patients: a 10-year regional laboratory experience. Hong Kong Med J 2018(4);24:340-9.

51. Guo X, Fan C, Tian L, Liu Y, Wang H, Zhao S, et al. The clinical features, outcomes and genetic characteristics of hypertrophic cardiomyopathy patients with severe right ventricular hypertrophy. PLoS One 2017(3);12:e0174118.

52. De Bortoli M, Calore C, Lorenzon A, Calore M, Poloni G, Mazzotti E, et al. Co-inheritance of mutations associated with arrhythmogenic cardiomyopathy and hypertrophic cardiomyopathy. Eur J Hum Genet 2017(10);25:1165-9.

53. Teirlinck CH, Senni F, Malti RE, Majoor-Krakauer D, Fellmann F, Millat G, et al. A human MYBPC3 mutation appearing about 10 centuries ago results in a hypertrophic cardiomyopathy with delayed onset, moderate evolution but with a risk of sudden death. BMC Med Genet 2012;13:105.

54. Page SP, Kounas S, Syrris P, Christiansen M, Frank-Hansen R, Andersen $\mathrm{PS}$, et al. Cardiac myosin binding protein- $\mathrm{C}$ mutations in families with hypertrophic cardiomyopathy: disease expression in relation to age, gender, and long term outcome. Circ Cardiovasc Genet 2012(2);5:156-66.

55. Ross SB, Bagnall RD, Ingles J, Van Tintelen JP, Semsarian C. Burden of recurrent and ancestral mutations in families with hypertrophic cardiomyopathy. Circ Cardiovasc Genet 2017(3);10:e001671.

56. Carniel E, Taylor MR, Sinagra G, Di Lenarda A, Ku L, Fain PR, et al Alpha-myosin heavy chain: a sarcomeric gene associated with dilated and hypertrophic phenotypes of cardiomyopathy. Circulation 2005(1);112:54-9.

57. Arai S, Matsuoka R, Hirayama K, Sakurai H, Tamura M, Ozawa T, et al. Missense mutation of the beta-cardiac myosin heavy-chain gene in hypertrophic cardiomyopathy. Am J Med Genet 1995(3);58:267-76.

58. Feng $X, \mathrm{He} T$, Wang JG, Zhao P. Asn391Thr mutation of $\beta$-myosin heavy chain in a hypertrophic cardiomyopathy family. Int Heart $J$ 2018(3);59:596-600

59. Montag J, Syring M, Rose J, Weber AL, Ernstberger P, Mayer AK, et al. Intrinsic MYH7 expression regulation contributes to tissue level allelic imbalance in hypertrophic cardiomyopathy. J Muscle Res Cell Motil 2017(3-4);38:291-302

60. Wang B, Guo RQ, Wang J, Yang F, Zuo L, Liu Y, et al. The cumulative effects of the myh7-v878a and cacna1c-a1594v mutations in a chinese family with hypertrophic cardiomyopathy. Cardiology 2017(4);138:228-37.

61. Wang C, Hata Y, Hirono K, Takasaki A, Ozawa SW, Nakaoka H, et al. $A$ wide and specific spectrum of genetic variants and genotype-phenotype correlations revealed by next-generation sequencing in patients with left ventricular noncompaction. J Am Heart Assoc 2017(9);6:e006210.

62. Wang B, Guo R, Zuo L, Shao H, Liu Y, Wang Y, et al. Analysis of genotype and phenotype correlation of MYH7-V878A mutation among ethnic Han Chinese pedigrees affected with hypertrophic cardiomyopathy. Zhonghua Yi Xue Yi Chuan Xue Za Zhi 2017(4);34:514-8.

63. Gawor M, Bilińska ZT, Franaszczyk M, Michalak E, Rafał P, Grzybowski J. A new missense mutation, p.Arg719Leu, of the beta-myosin heavy chain gene in a patient with familial hypertrophic cardiomyopathy. Minerva Cardioangiol 2017(1);65:96-102.

64. Montag J, Kowalski K, Makul M, Ernstberger P, Radocaj A, Beck J, et al Burst-like transcription of mutant and wildtype myh7-alleles as possible origin of cell-to-cell contractile imbalance in hypertrophic cardiomyopathy. Front Physiol 2018;359:9
65. Wang J, Wan K, Sun J, Li W, Liu H, Han Y3, et al. Phenotypic diversity identified by cardiac magnetic resonance in a large hypertrophic cardiomyopathy family with a single MYH7 mutation. Sci Rep 2018(1);8:973.

66. Guo X, Fan C, Wang Y, Wang M, Cai C, Yang Y, et al. Genetic anticipation in a special form of hypertrophic cardiomyopathy with sudden cardiac death in a family with 74 members across 5 generations. Medicine (Baltimore) 2017(11);96:e6249.

67. Yang KC, Breitbart A, De Lange W, Hofsteen P, Futakuchi-Tsuchida A, et al. Novel adult-onset systolic cardiomyopathy due to myh7 e848g mutation in patient-derived induced pluripotent stem cells. JACC Basic TransI Sci 2018(6);3:728-40.

68. Lu C, Wu W, Liu F, Yang K, Li J, Liu Y, et al. Molecular analysis of inherited cardiomyopathy using next generation semiconductor sequencing technologies. J Transl Med 2018(1);16:241.

69. Goel N, Huddleston CB, Fiore AC. A novel mutation of the MYH7 gene in a patient with hypertrophic cardiomyopathy. Turk J Pediatr 2018(3);60:315-8.

70. Kabaeva ZT, Perrot A, Wolter B, Dietz R, Cardim N, Correia JM, et al. Systematic analysis of the regulatory and essential myosin light chain genes: genetic variants and mutations in hypertrophic cardiomyopathy. Eur J Hum Genet 2002(11);10:741-8.

71. Flavigny J, Richard P, Isnard R, Carrier L, Charron P, Bonne G, et al. Identification of two novel mutations in the ventricular regulatory myosin light chain gene (MYL2) associated with familial and classical forms of hypertrophic cardiomyopathy. J Mol Med (Berl) 1998(3-4);76:208-14

72. Li L, Bainbridge MN, Tan Y, Willerson JT, Marian AJ. A potential oligogenic etiology of hypertrophic cardiomyopathy: a classic single-gene disorder. Circ Res 2017(7);120:1084-90.

73. Jay A, Chikarmane R, Poulik J, Misra VK. Infantile hypertrophic cardiomyopathy associated with a novel MYL3 mutation. Cardiology 2013(4);124:248-51

74. Olson TM, Karst ML, Whitby FG, Driscoll DJ. Myosin light chain mutation causes autosomal recessive cardiomyopathy with mid-cavitary hypertrophy and restrictive physiology. Circulation 2002(20);105:2337-40.

75. Arad M, Penas-Lado M, Monserrat L, Maron BJ, Sherrid M, Ho CY, et al. Gene mutations in apical hypertrophic cardiomyopathy. Circulation 2005(18);112:2805-11.

76. Girolami F, lascone M, Tomberli B, Bardi S, Benelli M, Marseglia G, et al. Novel $\alpha$-actinin 2 variant associated with familial hypertrophic cardiomyopathy and juvenile atrial arrhythmias: a massively parallel sequencing study. Circ Cardiovasc Genet 2014(6);7:741-50.

77. Chiu C, Bagnall RD, Ingles J, Yeates L, Kennerson M, Donald JA, et al. Mutations in alpha-actinin-2 cause hypertrophic cardiomyopathy: a genome-wide analysis. J Am Coll Cardiol 2010(11);55:1127-35.

78. Geier C, Gehmlich K, Ehler E, Hassfeld S, Perrot A, Hayess K, et al. Beyond the sarcomere: CSRP3 mutations cause hypertrophic cardiomyopathy. Hum Mol Genet 2008(18)17:2753-65.

79. Janin A, Bessière $F$, Chauveau $S$, Chevalier $P$, Millat $G$. First identification of homozygous truncating CSRP3 variants in two unrelated cases with hypertrophic cardiomyopathy. Gene 2018;676:110-116.

80. Theis JL, Bos JM, Bartleson VB, Will ML, Binder J, Vatta M, et al. Echocardiographic-determined septal morphology in Z-disc hypertrophic cardiomyopathy. Biochem Biophys Res Commun 2006(4);351:896-902.

81. Osio A, Tan L, Chen SN, Lombardi R, Nagueh SF, Shete S, et al. Myozenin 2 is a novel gene for human hypertrophic cardiomyopathy. Circ Res 2007(6);100:766-8.

82. Purevjav E, Arimura T, Augustin S, Huby AC, Takagi K, Nunoda S, et al Molecular basis for clinical heterogeneity in inherited cardiomyopathies due to myopalladin mutations. Hum Mol Genet 2012(9);21:2039-53.

83. Wang H, Li Z, Wang J, Sun K, Cui Q, Song L, et al. Mutations in NEXN, a Z-disc gene, are associated with hypertrophic cardiomyopathy. Am J Hum Genet 2010(5);87:687-93.

84. Hayashi T, Arimura T, Itoh-Satoh M, Ueda K, Hohda S, Inagaki N, et al. Tcap gene mutations in hypertrophic cardiomyopathy and dilated cardiomyopathy. J Am Coll Cardiol 2004(11);44:2192-201.

85. Campuzano $\mathrm{O}$, Sánchez-Molero $\mathrm{O}$, Mademont-Soler I, Riuró $\mathrm{H}$ Allegue $\mathrm{C}$, Coll $\mathrm{M}$, et al. Rare titin (TTN) variants in diseases associated with sudden cardiac death. Int J Mol Sci 2015(10);16:25773-87.

86. Vasile VC, Will ML, Ommen SR, Edwards WD, Olson TM, Ackerman MJ. Identification of a metavinculin missense mutation, R975W, associated with both hypertrophic and dilated cardiomyopathy. Mol Genet Metab 2006(2);87:169-74

87. Chiu C, Tebo M, Ingles J, Yeates L, Arthur JW, Lind JM, et al. Genetic screening of calcium regulation genes in familial hypertrophic cardiomyopathy. J Mol Cell Cardiol 2007(3);43:337-43

88. Landstrom AP, Kellen CA, Dixit SS, van Oort RJ, Garbino A, Weisleder N, et al. Junctophilin-2 expression silencing causes cardiocyte hypertrophy and abnormal intracellular calcium-handling. Circ Heart Fail 2011(2);4:21423.

89. Vanninen SUM, Leivo K, Seppälä EH, Aalto-Setälä K, Pitkänen O, Suursalmi $\mathrm{P}$, et al. Heterozygous junctophilin-2 (JPH2) p.(Thr161Lys) is a monogenic cause for HCM with heart failure. PLoS One 2018(9);13: e0203422. 
90. Minamisawa S, Sato Y, Tatsuguchi Y, Fujino T, Imamura S, Uetsuka $Y$, et al. Mutation of the phospholamban promoter associated with hypertrophic cardiomyopathy. Biochem Biophys Res Commun 2003(1);304:1-4.

91. Hayashi T, Arimura T, Ueda K, Shibata H, Hohda S, Takahashi M, et al. Identification and functional analysis of a caveolin-3 mutation associated with familial hypertrophic cardiomyopathy. Biochem Biophys Res Commun 2004(1);313:178-84.

92. Stull JT, Kamm KE, Vandenboom R. Myosin light chain kinase and the role of myosin light chain phosphorylation in skeletal muscle. Arch Biochem Biophys 2011(2);510:120-8.

93. Banankhah P, Fishbein GA, Dota A, Ardehali R. Cardiac manifestations of PRKAG2 mutation. BMC Med Genet 2018(1)19:1.

94. Torok RD, Austin SL, Phornphutkul C, Rotondo KM, Bali D2, Tatum GH et al. PRKAG2 mutations presenting in infancy. J Inherit Metab Dis 2017(6);40:823-30.

95. Xu Y, Gray A, Hardie DG, Uzun A, Shaw S, Padbury J, et al. A novel, de novo mutation in the PRKAG2 gene: infantile-onset phenotype and the signaling pathway involved. Am J Physiol Heart Circ Physiol 2017(2);313:H283-92.

96. Yang KQ, Lu CX, Zhang Y, Yang YK, Li JC, Lan T, et al. A novel PRKAG2 mutation in a Chinese family with cardiac hypertrophy and ventricular pre-excitation. Sci Rep 2017(1);7:2407.

97. Kelly BP, Russell MW, Hennessy JR, Ensing GJ. Severe hypertrophic cardiomyopathy in an infant with a novel PRKAG2 gene mutation: potential differences between infantile and adult onset presentation. Pediatr Cardiol 2009(8)30:1176-9.

98. Laforêt P, Richard P, Said MA, Romero NB, Lacene E, Leroy JP, et al A new mutation in PRKAG2 gene causing hypertrophic cardiomyopathy with conduction system disease and muscular glycogenosis. Neuromuscul Disord 2006(3);16:178-82.

99. Richard $\mathrm{P}$, Charron $\mathrm{P}$, Carrier L, Ledeuil $\mathrm{C}$, Cheav T, Pichereau $\mathrm{C}$, et al. Hypertrophic cardiomyopathy: distribution of disease genes, spectrum of mutations, and implications for a molecular diagnosis strategy. Circulation 2003(17); 107:2227-32

100. García-Castro M, Coto E, Reguero JR, Berrazueta JR, Álvarez V, Alonso $B$, et al. Espectro mutacional de los genes sarcoméricos $\mathrm{MYH7}$ MYBPC3, TNNT2, TNNI3 y TPM1 en pacientes con miocardiopatía hipertrófica. Rev Esp Cardiol 2009(1)62:48-56.

101. Olivotto I, Girolami F, Ackerman MJ, Nistri S, Bos JM, Zachara E, et al. Myofilament protein gene mutation screening and outcome of patients with hypertrophic cardiomyopathy. Mayo Clin Proc 2008(6);83:630-8.

102. Jongbloed RJ, Marcelis CL, Doevendans PA, Schmeitz-Mulkens JM, Van Dockum WG, Geraedts JP, et al. Variable clinical manifestation of a novel missense mutation in the alpha-tropomyosin (TPM1) gene in familial hypertrophic cardiomyopathy. J Am Coll Cardiol 2003(6);41:981-6.

103. Song JS, Kang JS, Kim YE, Park SJ, Park KM, Huh J, et al. Identification of pathogenic variants in genes related to channelopathy and cardiomyopathy in Korean sudden cardiac arrest survivors. J Hum Genet 2017(6);62:615-20.

104. Wang $Y$, Wang Z, Yang Q, Zou Y, Zhang H, Yan C, et al. Autosomal recessive transmission of $\mathrm{MYBPC} 3$ mutation results in malignant phenotype of hypertrophic cardiomyopathy. PLoS One 2013(6);8:e67087.

105. Calore C, De Bortoli M, Romualdi C, Lorenzon A, Angelini A, Basso C, et al. A founder MYBPC3 mutation results in $\mathrm{HCM}$ with a high risk of sudden death after the fourth decade of life. J Med Genet 2015(5);52:338-47.

106. Fourey D, Care M, Siminovitch KA, Weissler-Snir A, Hindieh W, Chan $\mathrm{RH}$, et al. Prevalence and clinical implication of double mutations in hypertrophic cardiomyopathy: revisiting the gene-dose effect. Circ Cardiovasc Genet 2017(2);10:e001685

107. Guo Q, Xu Y, Wang X, Guo Y, Xu R, Sun K, Chen S. Exome sequencing identifies a novel MYH7 p.G407C mutation responsible for familial hypertrophic cardiomyopathy. DNA Cell Biol 2014(10);44:699-704.

108. Ko YL, Chen JJ, Tang TK, Cheng JJ, Lin SY, Liou YC, et al. Malignan familial hypertrophic cardiomyopathy in a family with a 453Arg-->Cys mutation in the beta-myosin heavy chain gene: coexistence of sudden death and end-stage heart failure. Hum Genet 1996(5);97:585-90.

109. Andersen PS, Hedley PL, Page SP, Syrris P, Moolman-Smook JC, McKenna WJ, et al. A novel Myosin essential light chain mutation causes hypertrophic cardiomyopathy with late onset and low expressivity. Biochem Res Int 2012;2012:685108.
110. Previs MJ, Beck Previs S, Gulick J, Robbins J, Warshaw DM. Molecular mechanics of cardiac myosin-binding protein $C$ in native thick filaments. Science 2012(6099);337:1215-8.

111. Gaffin RD, Peña JR, Alves MS, Dias FA, Chowdhury SA, Heinrich LS, et al. Long-term rescue of a familial hypertrophic cardiomyopathy caused by a mutation in the thin filament protein, tropomyosin, via modulation of a calcium cycling protein. J Mol Cell Cardiol 2011(5);51:812-20.

112. Knöll R. Myosin binding protein C: implications for signal-transduction. J Muscle Res Cell Motil 2012(1);33:31-42.

113. Tanjore RR, Rangaraju A, Kerkar PG, Calambur N, Nallari P. MYBPC3 gene variations in hypertrophic cardiomyopathy patients in India. Can J Cardiol 2008(2);24:127-30.

114. Warkman AS, Whitman SA, Miller MK, Garriock RJ, Schwach CM, Gregorio CC, et al. Developmental expression and cardiac transcriptional regulation of Myh7b, a third myosin heavy chain in the vertebrate heart. Cytoskeleton (Hoboken) 2012(5);69:324-35.

115. Cuda G, Fananapazir L, Zhu WS, Sellers JR, Epstein ND. Skeletal muscle expression and abnormal function of beta-myosin in hypertrophic cardiomyopathy. J Clin Invest 1993(6);91:2861-5

116. Lankford EB, Epstein ND, Fananapazir L, Sweeney HL. Abnormal contractile properties of muscle fibers expressing beta-myosin heavy chain gene mutations in patients with hypertrophic cardiomyopathy. J Clin Invest 1995(3);95:1409-14.

117. Wang S, Zou Y, Fu C, Xu X, Wang J, Song L, et al. Worse prognosis with gene mutations of beta-myosin heavy chain than myosin-binding protein $\mathrm{C}$ in Chinese patients with hypertrophic cardiomyopathy. Clin Cardiol 2008(3);31:114-8.

118. Carrier L, Bonne G, Bährend E, Yu B, Richard P, Niel F, et al. Organization and sequence of human cardiac myosin binding protein $C$ gene (MYBPC3) and identification of mutations predicted to produce truncated proteins in familial hypertrophic cardiomyopathy. Circ Res 1997(3); 80:427-34.

119. Harris SP, Lyons RG, Bezold KL. In the thick of it: HCM-causing mutations in myosin binding proteins of the thick filament. Circ Res 2011(6);108:751-64

120. Lin J, Zheng DD, Tao Q, Yang JH, Jiang WP, Yang XJ, et al. Two novel mutations of the MYBPC3 gene identified in Chinese families with hypertrophic cardiomyopathy. Can J Cardiol 2010(10);26:518-22.

121. Epstein ND, Fananapazir L, Lin $\mathrm{HJ}$, Mulvihill J, White R, Lalouel JM,et al. Evidence of genetic heterogeneity in five kindreds with familial hypertrophic cardiomyopathy. Circulation 1992(2);85:635-47.

122. Frisso $G$, Limongelli $G$, Pacileo $G$, Del Giudice A, Forgione L, Calabrò $P$, et al. A child cohort study from southern Italy enlarges the genetic spectrum of hyper-trophic cardiomyopathy. Clin Genet 2009(1); 76:91-101.

123. Anan R, Greve G, Thierfelder L, Watkins H, McKenna WJ, Solomon S, et al. Prognostic implications of novel beta cardiac myosin heavy chain gene mutations that cause familial hypertrophic cardiomyopathy. $\mathrm{J}$ Clin Invest 1994(1):93:280-5.

124. Hwang TH, Lee WH, Kimura A, Satoh M, Nakamura T, Kim MK,et al. Early expression of a malignant phenotype of familial hypertrophic cardiomyopathy associated with a Gly716Arg myosin heavy chain mutation in a Korean family. Am J Cardiol 1998(12):82:1509-13.

125. Marian AJ, Mares A Jr, Kelly DP, Yu QT, Abchee AB, Hill R, et al. Sudden cardiac death in hypertrophic cardiomyopathy. Variability in phenotypic expression of beta-myosin heavy chain mutations. Eur Heart $J$ 1995(3);16:368-76

126. Epstein ND, Cohn GM, Cyran F, Fananapazir L. Differences in clinical expression of hypertrophic cardiomyopathy associated with two distinct mutations in the beta-myosin heavy chain gene. A 908Leu---Val mutation and a 403Arg----Gln mutation. Circulation 1992(2); 86:345-52.

127. Marian AJ, Yu QT, Mares A Jr, Hill R, Roberts R, Perryman M. Detection of a new mutation in the beta-myosin heavy chain gene in an individual with hypertrophic cardiomyopathy. J Clin Invest 1992(6);90:2156-65.

128. Watkins $H$, Rosenzweig A, Hwang DS, Levi T, McKenna W, Seidman CE, et al. Characteristics and prognostic implications of myosin missense mutations in familial hypertrophic cardiomyopathy. $\mathrm{N}$ Engl $\mathrm{J}$ Med 1992(17);326:1108-14 